\title{
Exploring the Use of Digital Materials in Teaching Graduate Accounting
}

\author{
James K. Page
}

\begin{abstract}
The use of digital materials in higher education is an integral part of graduate student learning to enhance twenty-first-century skills. Higher education institutions have witnessed an influx of graduate students who prefer the use of digital materials. Digital materials include online assignments, quizzes, and tests.

The purpose of this study was to investigate the traditional approach to teaching graduate accounting with textbook only in comparison to teaching with the use of digital materials. The aim was to introduce students to the use of digital materials and how it could be used to enhance their twenty-first-century skills. The primary goal of the study was to determine whether the treatment group learned more than the control group taught in the previous semester the non-traditional approach.

The null hypothesis for this study states that there was no difference in student learning outcomes between the group of students who learned using digital materials and students who learned the same course using traditional methods. The mixed-methods study design shed light on the research through the quantitative (cross-sectional) that supported the null hypothesis on the assignment grade section. The results indicate that while there were significant improvements in the overall final grades in the treatment group, the overall final grades of the control group were significantly lower.
\end{abstract}

In conclusion, the use of digital materials alone is not enough to result in enhancing twenty-firstcentury skills. The study indicated that teaching graduate accounting should include every effective resource at the disposal of the instructor.

\section{Introduction}

Colleges and Universities want to meet the needs of the workforce. This requires the use of the digital material in the classroom to help students enhance their twenty-first-century skills, such as think critically, solve complex open-ended problems and make innovative use of knowledge and information. Acquiring these skills is dependent upon non-traditional classrooms that foster creative and innovative learning environments (National Center on Education and the Economy [NCEE], 2006). Additional research emphasized the results of an online survey that found threefourths of employers said preference was given to graduates that possess the ability to communicate, critically think, and problem solves (Cavagnaro \& Fasihuddin, 2016; Tysiac, 2013). In other words, as Andersen (2013) says, "Classrooms must cultivate a culture of innovation" (p. 205) that prepares graduates to add value to whatever they do. Andersen (2013) further elaborates that effective teaching strategies "nurture the development of innovators" (p. 205). Instructors of all disciplines must assist in developing future innovators. There remains a challenge for higher education instructors to meet this workplace demand (Behar-Horentstein \& Niu, 2011).

For that reason, higher education publishers, such as Cengage Learning, recognize that accounting instructors require new, innovative tools to assist with the development of twenty-first-century 
skills prior to students entering the workforce (Cengage, 2013). According to Cengage (2013), technological advances, such as online learning and instructional interfacing like CengageNOW, changed the nature of course delivery and student interactions. These advanced non-traditional, digital materials significantly increased workplace readiness, student access, and student choice (Cengage, 2013).

This study took place at a private northeastern university whose prime mission is to bring theory and practice together (Uob, 2016). The study determines if achievement of college students enrolled in the graduate financial accounting course taught by traditional methods, such as lecture and textbook questions, and by non-traditional methods using digital materials designed to enhance twenty-first-century skills and increase learning outcomes.

The course is an introduction to American financial accounting principles that include the measurement, processing, and communication of accounting information. Users of such accounting information include business owners and others interested in financial conditions of an entity and the results of its operations (UoB, 2016). Employers are seeking students who are proficient with twenty-first-century skills. Institutions of higher education are seeking ways to meet this need.

\section{Purpose of The Study}

The purpose of this cross-sectional study was to compare student learning outcomes in a financial accounting course in a private northeastern university, based on the use of a textbook with the addition of digital materials in comparison to a group that only used a textbook and textbook discussions. Emphasis was placed on the use of digital materials that enhance twenty-first-century skills, a priority for employers hiring accounting graduates.

The study investigated faculty and student perceptions of the use of a non-traditional digital management learning tool product. Further, the study investigated whether students improved their critical thinking and problem-solving skills in preparation for the workplace by comparing end-ofcourse grades.

\section{Methodology}

This research followed a mixed-methods study design. This study conducted a quantitative (crosssectional) and qualitative (interview) approach to evaluate the impact and effectiveness of incorporating digital materials into a financial accounting course. The rationale for utilizing the mixed-methods research design was to address the research questions by looking at how an instructor's perspective about teaching accounting, using non-traditional digital materials supports the quantitative results about the students' academic achievement, as compared to the same instructor who only uses traditional instructional methods in previous semesters. Creswell and Plano Clark (2012) stated: "A mixed-methods research design is a procedure for collecting, analyzing, and 'mixing' both quantitative and qualitative methods in a single study or a series of studies to understand a research problem" (p. 534). The cross-sectional study approach was chosen to assess the effectiveness of digital materials using a treatment group and a control group. The control group consisted of students enrolled in the financial accounting course in the Spring of 2016, who was taught by a traditional instructional method that utilized textbooks only. The 
control group only utilized institutional resources, such as Blackboard or Canvas, to upload homework. The treatment group consisted of students enrolled in the same course in the fall of 2016, with the same instructor, who utilized a textbook, which included myBusinessCourse, a digital tool. The myBusinessCourse digital tool has a complete online instruction and homework system integrated into the software. The textbook provides the option for instructors to utilize the textbook only or to incorporate the online instruction. Each group completed similar assignments.

\section{Results and analysis}

The investigation sought to determine if there was any difference in learning outcomes of students enrolled in the financial accounting course taught by a non-traditional instruction method and the outcomes for students who were instructed by a traditional method.

One professor taught a financial accounting course during the spring, 2016 semester using traditional methods and the same course during fall, 2016 using digital materials. He was interviewed about his experience teaching the same course with and without digital materials. Final grades, assignment grades and quiz grades for students who used digital materials in the fall, 2016 section were compared to grades of students who did not use digital materials in the spring, 2016 section. Additionally, students in the fall 2016 section were surveyed to shed light on the value they placed on the digital materials, and to examine their perceived preparation for employment using twenty-first-century skills.

When the student survey was administered, the total course enrollment consisted of 27 students in ACCT400: Financial Accounting during the fall, 2016 semester at the private institution. Active, registered students in this course were asked to participate in the study. When the paper survey was distributed to the class, 24 active students were present. All 24 students present were offered the opportunity to participate in the research study.

Student scores were obtained to determine if there were significant differences in student learning outcomes because of the use of digital materials, as shown in Table 2. The spring, 2016 semester students' end-of-course grades, without the use of digital materials was higher for final grades and assignments, but not for quizzes. The fall, 2016 semester students who used digital materials show higher quiz grades, but lower final and assignments grades.

Table 2

t-test: Independent Samples for Group Taught by Traditional Methods and Group Taught with Digital materials

\begin{tabular}{|c|c|c|c|c|c|}
\hline \multirow[t]{2}{*}{ Sections } & \multicolumn{2}{|c|}{ Traditional $(n=14)$} & \multicolumn{3}{|c|}{ Digital Material $(n=26)$} \\
\hline & $M$ & $S D$ & $M$ & $S D$ & $t$ \\
\hline Final Grades & 90 & 18 & 73 & 7 & $3.32 *$ \\
\hline Assignments & 75 & 14 & 70 & 7 & 1.22 \\
\hline Quizzes & 76 & 23 & 90 & 12 & $-2.04 * *$ \\
\hline
\end{tabular}

${ }^{*} p<.05, * * p<.10$ 
A $t$-test for independent samples was performed on the final grades, assignments, and the quizzes, as shown in Table 2 . The value for final grades showed a statistically significant difference, $t_{(38)}=$ $3.32, p<.05$. The value for quizzes showed a statistically significant difference, $t_{(38)}=-2.04, p<$ .10. This indicates that the course taught without the use of digital materials yielded significantly higher final scores than the one taught with digital materials. The course taught with the use of digital materials yielded significantly higher quiz scores than the one taught without digital materials. The $t$-test for independent samples results for the assignments showed no statistically significant difference between groups, $t_{(38)}=1.22, p>.05$. The mean for the assignments without digital materials $(M=75, S D=14)$ was slightly higher than the mean for the assignments with the use of digital materials $(\mathrm{M}=70, \mathrm{SD}=7)$.

The student survey included response categories, such as Strongly Agree, Agree, Neutral, Disagree, and Strongly Disagree. Four categories of the survey included twenty-first-century skills gained while using digital materials, such as critical thinking knowledge, accounting skills, preparation for the workplace, and active learning skills, as shown in Table 3.

Table 3

Students' Opinion on Digital Materials and its Impact on Professional Development $(\mathrm{n}=24)$

\begin{tabular}{llllll}
\hline Skills & $\begin{array}{l}\text { Strongly } \\
\text { Agree } \\
(\%)\end{array}$ & $\begin{array}{l}\text { Agree } \\
(\%)\end{array}$ & $\begin{array}{l}\text { Neutral } \\
(\%)\end{array}$ & $\begin{array}{l}\text { Disagree } \\
(\%)\end{array}$ & $\begin{array}{l}\text { Strongly } \\
\text { Disagree } \\
(\%)\end{array}$ \\
\hline Critical thinking knowledge & 8 & 79 & 0 & 13 & 0 \\
Gain accounting skills & 8 & 79 & 0 & 13 & 0 \\
$\begin{array}{l}\text { Preparation for the workplace } \\
\text { Active learning prepares for the }\end{array}$ & 8 & 71 & 0 & 21 & 0 \\
workplace & 8 & 75 & 0 & 17 & 0 \\
\hline
\end{tabular}

When these 24 students were asked how they felt about critical thinking knowledge and accounting skills gained, $79 \%$ agreed the use of digital materials had an impact on their professional development skills. Additionally, $71 \%$ agreed they were gaining accounting skills through their experience using digital materials. Comparatively, $75 \%$ agreed active learning prepares them for the workplace using digital materials. Furthermore, the student survey revealed that most of the students $(75 \%)$ used digital materials in prior courses. Although $75 \%$ of the students had previous experience using digital materials, their performance on final scores was lower than students from the spring semester who did not use digital materials. Most of them agreed that digital materials can have a positive impact on professional skill. 


\section{Discussion}

The graduate financial accounting course included in this study prepares students primarily for managerial positions in accountancy. Many of the student participants eventually will become employed in business, government, and nonprofit organizations.

\section{Conclusion}

Overall, this study demonstrates that despite the recent steps forward in the use of non-traditional instruction with the use of digital materials, the traditional manner of lecturing will continue to be a part of the classroom learning environment. Although traditional instruction has value, so does digital materials. A blend of the two would be beneficial for students. For example, the professor emphasized the advantages of the digital materials, such as the interactive element of the homework. It provides instant feedback in the form of suggestions and tips, rather than just telling a student that he or she got the question wrong. It forces the user to look at the problem from multiple angles to answer the problem correctly. Students who enrolled in the graduate financial accounting course can easily continue to use digital materials as they continue their education through their graduate studies. The instructor felt the use of digital materials made teaching easier and improved student learning but stated that lecture-style, traditional teaching must still accompany courses that use digital materials.

The emphasis of this research is the implementation of the use of digital materials in a graduate financial accounting course and its impact on course grades and twenty-first-century skills gained in preparation for the workplace. The study investigated one professor who taught the same course in the same manner, but with a different format and style. Results from the $t$-test for the independent samples provided valuable insight into this study.

This research found that the use of digital materials significantly impacted the quiz section of the course in a positive direction. The assignments section was not significantly impacted using digital materials. In contrast, the final grades of the course that used digital materials were negatively impacted in a significant manner. The professor and the students in this study experienced several setbacks during the course that used digital materials; however, the professor has continued to use digital materials in the other graduate financial accounting courses. 


\section{References}

Andersen, L. (2013). Creating Innovators: The making of young people who will change the world. Wagner, T (2012). Roeper Review, 35(3), 205-206. doi:10.1080/02783193.2013.795479

Behar-Horenstein, L., \& Niu, L. (2011). Teaching critical thinking skills in higher education: A review of the literature. Journal of College Teaching and Learning, 8(2), 25-41.

Cavagnaro, L.B., \& Fasihuddin, H. (2016). A moonshot approach to change in higher education: Creativity, innovation, and the redesign of academia. Liberal Education, 102(2). Retrieved from https://www.aacu.org/liberaleducation/2016/spring/cavagnaro

Cengage Learning. (2013). Student learning and engagement improve with CengageNOW: A study of the impact of Cengage Learning's CengageNOW on student learning [White paper]. Retrieved from Cengage Learning website: http://assets.cengage.com/pdf/ wp_cnow.pdf

Creswell, J. W., \& Plano Clark, V. (2012). Designing and conducting mixed methods research (4th ed.). Thousand Oaks, CA: Sage.

National Center on Education and the Economy. (2006). Tough choices or tough times: The report of the new commission on the skills of the American workforce - Executive summary. Retrieved from http://www.skillscommission.org/wp-content/uploads/ 2010/05/ToughChoices_EXECSUM.pdf

Tysiac, K., (2013, September 10). How finance and accounting can boost innovation. Journal of Accountancy. Retrieved from http://www.journalofaccountancy.com/news/2013/sep /20138692.html

University of Bridgeport. (2016). MBA with Accounting. Retrieved from http://www.bridgeport.edu/academics/graduate/master-business-administration$\mathrm{mba} / \mathrm{majors} /$ accounting 